\author{
Research Article \\ www.ijrap.net
}

\title{
UNEXPLORED WOUND HEALING PROPERTY OF EHTRETIA LAEVIS ROXB. (KHANDU CHAKKA) PLANT
}

\author{
Thakre Rushikesh ${ }^{1 *}$, Bhutada S. ${ }^{2}$, Chouragade B. ${ }^{3}$, Khobragade P. ${ }^{4}$, Harne Ketaki ${ }^{5}$ \\ ${ }^{1}$ PG Scholar, Department of Samhita, Mahatma Gandhi Ayurved College Hospital and Research centre, \\ Salod (H), Wardha, Maharashtra, India \\ ${ }^{2}$ Professor and Dean, Mahatma Gandhi Ayurved College Hospital and Research centre, \\ Salod (H), Wardha, Maharashtra, India \\ ${ }^{3}$ Professor and HOD Department of Sankrit-Samhita-Siddhant, Mahatma Gandhi Ayurved College Hospital and \\ Research centre, Salod (H), Wardha, Maharashtra, India \\ ${ }^{4}$ Associate Professor Department of Dravyaguna, Mahatma Gandhi Ayurved College Hospital and Research centre, \\ Salod (H), Wardha, Maharashtra, India \\ ${ }^{5}$ Quality Control Rasashala, Mahatma Gandhi Ayurved College Hospital and Research centre, \\ Salod (H), Wardha, Maharashtra, India
}

Received on: 16/08/16 Revised on: 16/09/16 Accepted on: 22/09/16

\author{
*Corresponding author \\ E-mail: dr.rushu@gmail.com
}

DOI: $10.7897 / 2277-4343.075219$

\begin{abstract}
There are many wound healing problems like infections, old age, stress, diabetics, chemotherapy drugs, obesity, alcohol consumption, smoking, mal nourishment. Lots of higher expensive antibiotics are used to treat wound infection. Patients have to face untoward effects of higher antibiotics. This plant is commonly used in Wardha district of Maharashtra India for wound healing, fractures, body ache by rural population. Local name of this plant is Khandu-Chakka. Available literatures reviewed, Fresh leaves were collected, Paste is prepared under all aseptic precaution. Patients were selected randomly from indoor and outdoor departments Hospitals. Daily, Paste in quantity sufficient was applied and the wound was closed properly with all aseptic precautions without using any antiseptic lotion and antibiotics till complete healing of wound with sample size of 34 patients. Patients were tested on thirteen parameters of Bates-Jensen Wound Assessment Tool against number of setting for dressing at the interval of seven days versus gender, age, fresh and chronic, infected and non infected wounds. One Way ANOVA test applied for Thirty four patient's analysis. Most of the wound healed within fifteen days. In Ayurvedic literature, uses of this plant for Diabetics and Antivenom are also mentioned but no any reference for wound healing. The study reveals that the wounds irrespective of age, sex, fresh and chronic, infected and non infected healed properly and completely from minimum seven days to maximum sixty six days, except one.
\end{abstract}

Key words: Charmavriksha, Ehretia laevis Roxb., Fracture, Joint pain, Khandu chakka, Wound healing.

\section{INTRODUCTION}

More over an effective drug is needed which can prevent, the entry of microbes in the wound or the one which promotes the wound healing or the both activities simultaneously done.

The prevalence of wounds in the Indian population studied $(\mathrm{n}=$ 6917) was 15.03 per 1000 . The prevalence of acute and chronic wounds was 10.55 and 4.48 per 1000 of the population respectively. In India, the most common site for both acute and chronic wounds was the lower extremity. In contrast to Western studies, the most common etiology for a chronic lower extremity wound was an untreated acute traumatic wound. ${ }^{1}$ Prevalence of foot infection is higher among rural than urban patients, Amputation rates are also higher among rural than urban patients. Recurrence of foot infection is higher among rural than urban patients. Surgical intervention is also more frequent among rural than urban patients. ${ }^{2}$

This plant contains many medicinally useful chemicals. In Wardha district of Maharashtra India, One herbal plant Ehretia laevis Roxb. was found to be very effective in wound healing. It is commonly used by tribal for wound management with surprising output. Also used for minor fractures and joint pain and known as Khandu Chakka plant. Wound healing property of this plant not mentioned in any literature.

Ehretia laevis is Commonly known as: ovate-leaved ivory wood, Gujarati: Vadhavaradi , Hindi: bhairi, chamror, Konkani: kalo gamdo, Malayalam: Caranti, Marathi:, Datrangi (As it colors teeth in red, Ajaanvruksha (Sant Dnyaneshwar From Alandi Maharashtra India took Samadhi near the base of this tree).

In Ayurvedic literature, uses of this plant are for Prameha (Diabetics) and Vishaghna (Anti-venom) (Su.Chi 11/10, Su.Kal.5/46, and Cha.Chi.23/66). This is probably due to Amino acid -Cysteine $e^{3-4}$ and $\mathrm{Di}-\mathrm{n}$ octyl phthalate ${ }^{5-6}$ respectively. This plant contains many medicinally useful chemicals and has great ethno botanical properties. ${ }^{7}$

\section{MATERIALS AND METHODS}

The Ayurvedic literatures were scrutinized regarding the references of Ehretia laevis Roxb. plant. Later references were studied from internet, research papers, local peoples, folklore practitioners. Plant is indentified by Taxonomist and Head of the Dravyaguna Department of MGACH \& RC Salod (H) 
Wardha. Fresh leaves of plant were collected from nearby area of our district. After verification of sample, Paste was prepared in Rasa- Shala, under supervision of subject expert. Leaves were washed with distilled water and then cleaned by absolute alcohol and then rinsed by distilled water three times. Paste was prepared in mortar and pestle. Mortar and pestle was autoclaved $121^{\circ} \mathrm{C}$ (121 PSI for $\left.20 \mathrm{~min}\right)$. Due to degradation of phytochemicals, leaves were not autoclaved. Thus paste was prepared. Patients were randomly selected from indoor and outdoor departments of Hospitals. Approval from institutional ethical committee was taken. Sample size Thirty four patients. Exclusion criteria-Burn, Leprosy, and Gangrenous wound, Neoplastic ulcer, Complicated wound wounds in which bone and vital parts exposed, Pregnancy.

Withdrawal Criteria- Patient not responding to the treatment and aggravation of symptoms. Proper consent was taken. Case papers were filled. Random blood sugar and complete blood culture were done. Detailed case record forms were filled including local and systemic examination.

Paste in quantity sufficient was applied and the wound was closed properly with all aseptic precautions. The wound was opened next day and dressing was done with changes if any. This procedure was continues till complete healing of wound.
Weekly Score was recorded in Bates-Jensen Wound Assessment tool. In none of cases except one, complication developed \& the subject was referred to surgery department \& was withdrawn from study.

\section{RESULTS AND OBSERVATION}

Patients were tested on thirteen parameters of Bates-Jensen Wound Assessment Tool against number of setting for dressing at the interval of seven days versus gender, age, fresh and chronic, infected and non infected wounds status. One Way ANOVA test applied for Thirty four patient's analysis. Thirteen parameters are as follows Size, Depth Edge under mining, Necrotic tissue type Necrotic tissue amount Exudates type items, Exudates amount Skin color surrounding wound, Tissue edema, Peripheral tissue indurations, Granulation tissue, Epithelialization.

1. Thirteen parameters were tested against gender of patients. In the study there were twenty three male and eleven females.

Efficacy of Ehretia laevis Roxb. leaves paste in wound's Size, Depth, Edge, under mining, Necrotic tissue type, Necrotic tissue amount, Exudates type items, Exudates amount of wound Vs Gender

\begin{tabular}{|c|c|c|c|c|c|c|}
\hline Sr. No. & Gender & Frequency & Mean No. Of Setting of treatment required & SD & F-test & P-value \\
\hline 1 & Male & 23 & 2.33 & 0.761387 & 2.3499 & \multirow{2}{*}{0.1432} \\
\hline 2 & Female & 11 & 3.5 & 2.635231 & & \\
\hline
\end{tabular}

For size, Depth, Edge, under mining, Necrotic tissue type, Necrotic tissue amount, Exudates type items, Exudates amount of wound against gender P-value is 0.1432 is greater than 0.05 . However the efficacy of Ehretia laevis Roxb. leaves paste in above parameter against Gender is found no significant.
Efficacy of Ehretia laevis Roxb. leaves paste in wound's Skin color surrounding wound, Tissue edema, Peripheral tissue indurations, Granulation tissue, Epithe- lialization Vs Gender

\begin{tabular}{|c|c|c|c|c|c|c|}
\hline Sr. No. & Gender & Frequency & Mean No. Of Setting of treatment required & SD & F-test & P-value \\
\hline 1 & Male & 23 & 2.25 & 0.73721 & 2.83 & 0.18331 \\
\hline 2 & Female & 11 & 3.6 & 2.836273 & & \\
\hline
\end{tabular}

For Skin color surrounding wound, Tissue edema, Peripheral tissue indurations, Granulation tissue, Epithe- lialization of wound against gender P-value is 0.18331 is greater than 0.05 . However the efficacy of Ehretia laevis Roxb. leaves paste in above parameter against Gender is found no significant.

It shows that Ehretia laevis Roxb. leaves paste is efficient in wound healing irrespective of gender, and efficiently acts on both genders.

\section{Thirteen parameters were tested against age of patient}

\begin{tabular}{|c|c|}
\hline Age & Frequency of patient \\
\hline $18-25$ & 4 \\
\hline $26-33$ & 8 \\
\hline $34-40$ & 4 \\
\hline $41-47$ & 2 \\
\hline $48-55$ & 5 \\
\hline $56-60$ & 4 \\
\hline $61-69$ & 2 \\
\hline 70 and above & 5 \\
\hline
\end{tabular}

For size, Depth, Edge, under mining, Necrotic tissue type, Necrotic tissue amount, Exudates type items, Exudates amount of wound against age P-value is less than 0.05. However the efficacy of Ehretia laevis Roxb. leaves paste in above parameter against age is found significant. For Skin color surrounding wound, Tissue edema, Peripheral tissue indurations, Granulation tissue, Epithe- lialization of wound against age P-value is less than 0.05 .

However the efficacy of Ehretia laevis Roxb. leaves paste in above parameter against age is found significant. It shows that Ehretia laevis Roxb. leaves paste is efficient in wound healing even in old age patient. Maximum injuries were reported in the age group between 26-33.

3. Thirteen parameters were tested against chronic and fresh wound status of patients. There were total Thirty four patient contributed in study, out of which thirty one were fresh wound and three were chronic wound.

Efficacy of Ehretia laevis Roxb. leaves paste on wound's size, Depth, Edge, Under mining, Necrotic tissue type, Necrotic tissue amount, Exudates type items, Exudates amount Vs Chronic and fresh

\begin{tabular}{|c|c|c|c|c|c|c|}
\hline Sr. No. & Gender & Frequency & Mean No. Of Setting of treatment required & SD & F-test & P-value \\
\hline 1 & Chronic & 3 & 5.75 & 0.70 & 1.285 & 0.459 \\
\hline 2 & Fresh & 31 & 2.65 & 1.65 & & \\
\hline
\end{tabular}


For size, Depth, Edge, under mining, Necrotic tissue type, Necrotic tissue amount, Exudates type items, Exudates amount of wound against chronic and fresh wound status P-value is 0.459 is greater than 0.05 . However the efficacy of Ehretia laevis Roxb. leaves paste in above parameter against chronic and fresh wound status is found no significant.
Efficacy of Ehretia laevis Roxb. leaves paste in wound's Skin color surrounding wound, Tissue edema, Peripheral tissue indurations, Granulation tissue, Epithe- lialization of Wound Vs Chronic and fresh

\begin{tabular}{|c|c|c|c|c|c|c|}
\hline Sr. No. & Gender & Frequency & Mean No. Of Setting of treatment required & SD & F-test & P-value \\
\hline 1 & Chronic & 3 & 5.00 & 4.35 & 1.284 & 0.527 \\
\hline 2 & fresh & 31 & 2.41 & 0.99 & & \\
\hline
\end{tabular}

For Skin color surrounding wound, Tissue edema, Peripheral tissue indurations, Granulation tissue, Epithe- lialization of wound against chronic and fresh wound status P-value is 0.527 is greater than 0.05. However the efficacy of Ehretia laevis Roxb. leaves paste in above parameter against chronic and fresh wound status is found no significant.

It shows that Ehretia laevis Roxb. leaves paste is efficient in wound healing irrespective of chronic and fresh wound status, and efficiently acts on chronic and fresh wound status.
4. Thirteen parameters were tested against infected and non infected wound status of patients. There were total thirty four patients contributed in study out of which twenty eight were non infected wound and six were infected wound.

Efficacy of Ehretia laevis Roxb. leaves paste in wound's size, Depth, Edge, under mining, Necrotic tissue type, Necrotic tissue amount, Exudates type items, Exudates amount of wound Vs Infected and non infected.

\begin{tabular}{|c|c|c|c|c|c|c|}
\hline Sr. No. & Gender & Frequency & Mean No. Of Setting of treatment required & SD & F-test & P-value \\
\hline 1 & Infected & 6 & 6.1 & 1.095 & 42.96 & 0.375 \\
\hline 2 & Non-infected & 28 & 2.58 & 1.68 & & \\
\hline
\end{tabular}

For size, Depth, Edge, under mining, Necrotic tissue type, Necrotic tissue amount, Exudates type items, Exudates amount of wound against chronic and fresh wound status P-value is 0.375 is greater than 0.05 . However the efficacy of Ehretia laevis Roxb. leaves paste in above parameter against infected and non infected wound status is found no significant.
Efficacy of Ehretia laevis Roxb. leaves paste in wound's Skin color surrounding wound, Tissue edema, Peripheral tissue indurations, Granulation tissue, Epithe- lialization of wound Vs infected and Non- infected

\begin{tabular}{|c|c|c|c|c|c|c|}
\hline Sr. No. & Gender & Frequency & Mean No. Of Setting of treatment required & SD & F-test & P-value \\
\hline 1 & infected & 6 & 6.1 & 1.095 & 1.278 & 0.4545 \\
\hline 2 & Non-infected & 28 & 2.6 & 1.68 & & \\
\hline
\end{tabular}

For Skin color surrounding wound, Tissue edema, Peripheral tissue indurations, Granulation tissue, Epithe- lialization of wound against infected and non infected wound status P-value is 0.4545 is greater than 0.05 . However the efficacy of Ehretia laevis Roxb. leaves paste in above parameter against infected and non infected wound status is found no significant.

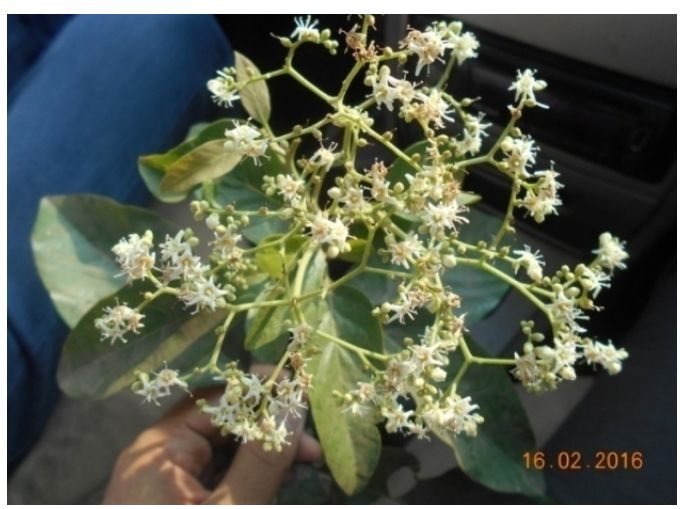

It shows that Ehretia laevis Roxb. leaves paste is efficient in wound healing irrespective of infected and non infected wound status, and efficiently acts on infected and non infected wound status. Most of the wound healed within fifteen days.

\section{Plant Photos}

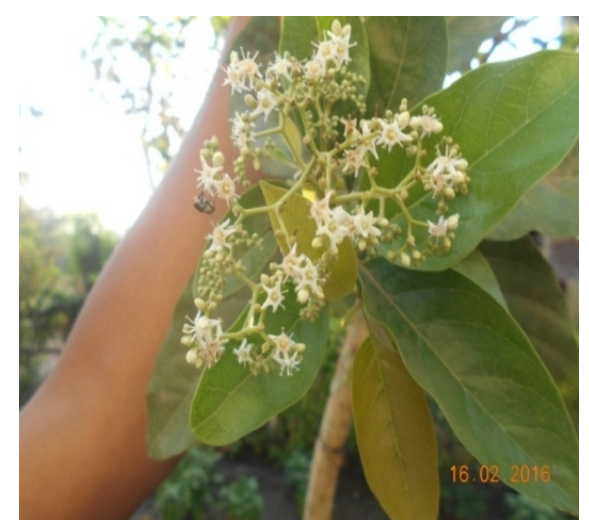




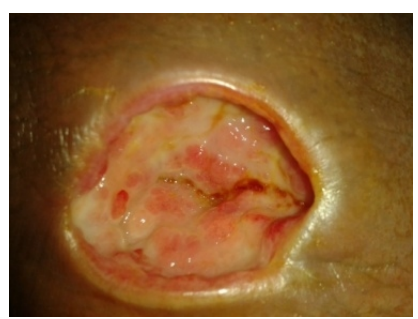

Before Treatment

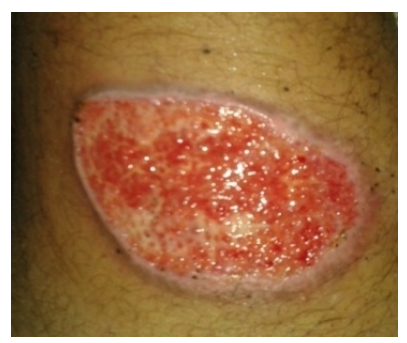

Before Treatment

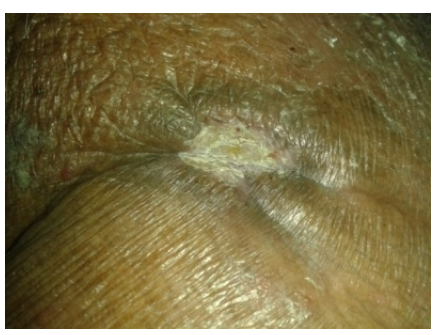

After Treatment

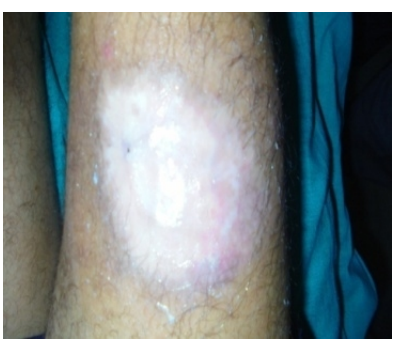

After Treatment

Wound Healing Photos

\section{DISCUSSION AND CONCLUSION}

The study revealed marked healing properties of Ehretia laevis Roxb. leaves paste in infected/non infected, chronic/ fresh wounds and more efficient in old age and time requirement from minimum seven days to maximum sixty six days

The best part is its leaves are effective and hence plenty of material is available without any requirement of uprooting of plant. This property has created a sense of conservation, preservation, and cultivation of the plant. The treatment is also very economic as only paste is to be prepared in aseptic condition. The study revealed that no antibiotics were required and hence the immunological status of patient was not hampered. Similarly there was huge saving in the medical expenditure, which is very important in developing country like India. Hence it would be one of the best options for crop cultivation in government declared farmer suicidal area like Wardha district of Maharashtra India. This small study has paved a big avenue in management of wound.

\section{REFERENCES}

1. Gupta N, Gupta SK, Shukla VK, Singh SPJ An Indian community-based epidemiological study of wounds. Wound Care. 2004 Sep;13(8):323-5

2. Viswanathan Vijay, Madhavan Sivagami, Rajasekar Seena, BA, Chamukuttan Snehalatha, and Ambady Ramachandran, Urban-Rural Differences in the Prevalence of Foot Complications in South-Indian Diabetic Patients. Diabetes Care, volume 29, number 3, March 2006.

3. Rasika C. Torane, Anjali D. Ruikar, Pranav S. Chandrachood and Nirmala R. Deshpande -Study of Amino Acids and Carbohydrates from The Leaves of Ehretia laevis Asian Journal of Chemistry Vol. 21, No. 2 (2009), 1636-1638.

4. University of Maryland Home, Health Information, Medical
Reference Guide, Complementary and Alternative Medicine Guide, Supplement, (homepage on the internet)available fromCysteinehttp://umm.edu/health/medical/altmed/supple ment/cysteine cited on 16/2/2016

5. Torane R C., Kamble Gayatri S., Gadkari Tushar V., Tambe Amruta S. and Deshpande Nirmala R., - GC MS Study of Nutritious leaves of Ehretia laevis, International Journal of ChemTech Research Vol. 3, No.3, pp 1589-1591, July-Sept 2011.

6. S. Ibrahim, J.A. Nok, M.S. Abubakar and S. Sarkiyayi, Efficacy of Di-n-octyl phthalate anti venom isolated from Ceiba pentandra leaves extract in neutralization of Echis ocellatus venom, Research Journal of Applied Sciences, Engineering and Technology 4(15):2382-2387 January 2012

7. Thakre Rushikesh, Bhutada S, Chouragade B, Khobragde P, Harne Ketaki. Ethano Botanical Properties of Unexplored Plant Khandu Chakka (Ehretia Laevis Roxb.). International Journal of Ayurveda and Pharma Research. 2016;4(7):6873.

8. PVSharma. Susruta Samhita (Dalhana commentary) $1^{\text {st }}$ edition Chaukhamba Samskruta Samsthana,Varanasi;1999

9. Haldar Pronab, Mishra DK, Mahapatra BN, Agrawal DS. Pharmaco - analytical and experimental study of Darvyaadi ghrita with special reference to Wound healing effect. Int. J. Res. Ayur. Pharm. 2013; 4(2):177-182 DOI: 10.7897/22774343.04217

\section{Cite this article as:}

Thakre Rushikesh, Bhutada S., Chouragade B., Khobragade P., Harne Ketaki. Unexplored wound healing property of Ehtretia laevis Roxb. (Khandu chakka) plant. Int. J. Res. Ayurveda Pharm. Sep - Oct 2016;7(Suppl 4):54-57 http://dx.doi.org/ $10.7897 / 2277-4343.075219$ every effort has been taken to verify the accuracy of the content published in our Journal. IJRAP cannot accept any responsibility or liability for the site content and articles published. The views expressed in articles by our contributing authors are not necessarily those of IJRAP editor or editorial board members. 